\title{
Hemoglobin C disease
}

INSERM

\section{Source}

INSERM. (1999). Orphanet: an online rare disease and orphan drug data base.

Hemoglobin C disease. ORPHA:2132

Hemoglobin $\mathrm{C}$ disease $(\mathrm{HbC}$ ) is a hemoglobinopathy characterized by production of abnormal variant hemoglobin known as hemog lobin C, with no or mild clinical manifestations (hemolytic anemia). 